\title{
OCENA REAKCJI STÓP ZWROTU AKCJI WYBRANYCH SPÓŁEK NA ZMIANY STOPY REFERENCYJNEJ Z WYKORZYSTANIEM WARUNKOWEJ ANALIZY ZDARZEŃ
}

\section{WSTEP}

Bardzo ważne dla inwestorów rynków akcji są informacje o ogólnym stanie gospodarki, a wśród nich ogłoszenia o poziomie podstawowych stóp procentowych banku centralnego. Spośród wszystkich stóp procentowych Narodowego Banku Polskiego (NBP) stopa referencyjna odgrywa najważniejszą rolę w gospodarce, stąd reakcja inwestorów na zmiany właśnie tej stopy procentowej została przeanalizowana w niniejszym opracowaniu. Celem badania jest ocena reakcji stóp zwrotu akcji polskiego rynku na ogłoszenia Rady Polityki Pieniężnej (RPP) dotyczące zmiany podstawowych stóp procentowych w latach 2004-2011. Ocena reakcji stóp zwrotu akcji na napływające na rynek informacje została przeprowadzona $\mathrm{z}$ wykorzystaniem metody warunkowej analizy zdarzeń.

Artykuł składa się z dwóch części. Pierwsza część, o charakterze teoretycznym, zawiera syntezę analogicznych badań na rynkach zagranicznych oraz prezentuje metodykę warunkowej analizy zdarzeń. W drugiej części przedstawiono wyniki autorskich badań reakcji stóp zwrotu rynku akcji na ogłoszenie informacji o zmianie stopy referencyjnej NBP.

\section{OCENA REAKCJI RYNKU NA OGLOSZENIA O STOPACH PROCENTOWYCH BANKÓW CENTRALNYCH NA PODSTAWIE DOTYCHCZAS PRZEPROWADZONYCH BADAŃ}

Zależność między zmianą poziomu podstawowych stóp procentowych a stopami zwrotu papierów wartościowych jest przedmiotem rozległych badań. Nie sposób ich wszystkich przytoczyć, dlatego przedstawiono wyniki tylko części przeprowadzonych badań. Warto jednak zaznaczyć, że zagadnienie to podejmowane było przez badaczy zarówno z zakresu polityki pieniężnej, jak i funkcjonowania rynków finansowych.

Podejmowana $\mathrm{w}$ pracy tematyka reakcji stóp zwrotu akcji na zmiany poziomu podstawowych stóp procentowych cieszy się na rynku amerykańskim 
zainteresowaniem od początku lat siedemdziesiątych $\mathrm{XX}$ w. Wówczas to R. N. Waud przedstawił wyniki badań przemawiające za występowaniem istotnej reakcji stóp zwrotu akcji na ogłoszenia o zmianie stopy dyskontowej. Analogiczne badania przedstawili M. Simrlock oraz J. Yawitz. Wskazali oni na negatywną reakcję stóp zwrotu na zmiany stopy dyskontowej, zaznaczając jednak, że wystąpiła ona dopiero po 1979 r., do okresu poprzedzającego zaś reakcji nie zaobserwowano. Istotną negatywną reakcję stóp zwrotu akcji po 1979 r. potwierdzono w badaniach G. R. Jensena oraz R. R. Johansona, jak również D. K. Pearce'a oraz V. V. Roleya. Następnie tematyka ta była podejmowana przez R. W. Hafera, który zaobserwował spadki (wzrost) kursów akcji po napłynięciu na rynek informacji o podwyżce (obniżce) stopy dyskontowej, ale tylko w latach 1979-1982. Natomiast dla okresu poprzedzającego i następującego zauważył on pozytywną reakcję (wzrost wywoływał wzrost) stóp zwrotu, choć $\mathrm{w}$ tym przypadku zmiany te nie były statystycznie istotne ${ }^{1}$. Kolejne badania, przeprowadzone przez G. A. Hardouvelisa, potwierdziły negatywna reakcję stóp zwrotu na nieoczekiwaną zmianę stopy dyskontowej w latach 1979-1982 oraz wskazały na brak reakcji w latach późniejszych ${ }^{2}$.

Interesujących wyników dostarczyły badania G. R. Jensena oraz R. R. Johansona, którzy w odróżnieniu od poprzedników, zbadali reakcję stóp zwrotu zarówno przed (dzień -15 do -1), w trakcie (dzień 0 oraz 1) oraz po (dzień 2 do 16) napłynięciu informacji na rynek. Stwierdzili oni negatywną zależność we wszystkich badanych okresach. Co ważne, uwzględnienie informacji o zmianach stopy dyskontowej w kursach akcji przed dniem zdarzenia tłumaczono prawidłowym kształtowaniem oczekiwań przez inwestorów w kwestii poziomu stóp procentowych banku centralnego. Podkreślono również, że zauważona reakcja stóp zwrotu w okresie od 2. do 16. dnia następująco po dniu podania informacji do publicznej wiadomości nie jest wynikiem opóźnionej reakcji inwestorów, gdyż reakcja ta w większości przypadków miała miejsce w dzień podania informacji ${ }^{3}$.

Badanie reakcji stóp zwrotu na zmiany poziomu podstawowej stopy banku centralnego dodatkowo $\mathrm{z}$ uwzględnieniem stanu gospodarki, wyrażonej za pomoca poziomu aktywności ekonomicznej (wysoki, średni, niski), zostało przeprowadzone przez G. McQueena oraz V. V. Roleya. W modelu zarówno z dodatkowymi zmiennymi wyrażającymi aktywność ekonomiczna, jak i bez nich nie zidentyfikowano statystycznie istotnej reakcji stóp zwrotu na zmiany poziomu stopy dyskontowej. Mimo to, warto jednak podkreślić fakt, że w sytuacji wysokiej aktywności ekonomicznej kierunek zmian stóp zwrotu oraz stóp dyskontowych był zgodny, a w pozostałych przypadkach kierunek był przeciwny ${ }^{4}$.

\footnotetext{
${ }^{1}$ P. Sellin, Monetary Policy and the Stock Market: Theory and Empirical Evidence, ,Journal of Economic Surveys" 15, 2001, nr 4, s. 491-541.

${ }^{2}$ G. A. Hardouvelis, Macroeconomic Information and Stock, „Journal of Economics and Business" 39, 1987, s. 131-140.

3 P. Sellin, s. 513.

${ }^{4}$ G. McQueen, V. V. Roley, Stock, Prices, News and Business Conditions, ,The Review of Financial Studies" 6, 1993, nr 3, s. 683-707.
} 
Następnie G. R. Jensen, J. M. Mercer i R. R. Johnson dowiedli, że reakcja stóp zwrotu walorów zależy od fazy cyklu gospodarczego oraz od charakteru prowadzonej polityki pieniężnej. Badania wykazały, że reakcja stóp zwrotu względem napływających na rynek informacji o stanie gospodarki jest istotna tylko w okresach prowadzenia ekspansywnej polityki pieniężnej. Późniejsze badania przeprowadzone przez $\mathrm{W}$. Thorbecke'a wykazały ponownie negatywna istotna statystycznie reakcję kursów akcji na zmiany stopy procentowej (bez względu na kierunek tych zmian). Ponadto W. Thorbecke dowiódł, że podwyżka stóp procentowych wywołuje silniejszą reakcję zwrotów w przypadku spółek o małej kapitalizacji niż spółek większych ${ }^{5}$.

Przedmiotem badania na rynku amerykańskim była reakcja stóp zwrotu nie tylko na zmiany stopy dyskontowej, lecz także stopy określającej minimalna rentowność operacji otwartego rynku. Tematykę ta podejmował V. Tahran, który wykazał na brak istotnej reakcji w stopach zwrotu. Natomiast W. Thorbedke, badając reakcję na zmiany stopy funduszy federalnych, wskazał na istnienie reakcji negatywnej ${ }^{6}$.

W Europie analogiczne badania przeprowadzono w Szwecji. Wykazały one, że zmiany stopy oprocentowania operacji otwartego rynku oraz stopy dyskontowej wywierają istotny wpływ na kształtowanie się stóp zwrotu akcji. Podobnie jak na rynku amerykańskim wpływ ten ma kierunek negatywny. Dodatkowo zauważono, że zmianie poziomu stopy repo towarzyszyła pozytywna reakcja zmienności stóp zwrotu akcji, a w przypadku zmiany stopy dyskontowej reakcja ta była negatywna. Szczególnie istotne wydaje się zauważony spadek zmienności stóp procentowych po konferencjach prasowych, na których tłumaczono zasadność podjętych decyzji. Fakt ten można interpretować jako usunięcie niepewności wśród inwestorów co do przyszłej ścieżki polityki pieniężnej ${ }^{7}$.

Badania H. Gurgula ${ }^{8}$ przeprowadzone na rynku polskim wykazały, że zmiana kierunku zmian stopy redyskontowej wywołuje wzrost kursów akcji w przypadku zarówno pierwszej podwyżki, jak i pierwszej redukcji poziomu tej stopy. Nie stwierdzono jednak wpływu zdarzenia na wielkość obrotu.

Podsumowując, historia badania reakcji stóp zwrotu polskich akcji na zmiany stóp procentowych NBP jest bardzo krótka i niezbyt rozwinięta. Tymczasem literatura zagraniczna bogata jest w wyniki analogicznych badań przeprowadzonych na rynkach dojrzałych. Na ich podstawie można wnioskować, że jeśli na polskim rynku będzie miała miejsce reakcja stóp zwrotu akcji na ogłoszenia decyzji o zmianie poziomu stopy referencyjnej, to będzie to reakcja negatywna.

P. Sellin, s. 495-496.

${ }^{6}$ Ibidem, s. 513.

7 Ibidem, s. 516.

${ }^{8}$ H. Gurgul, Analiza zdarzeń na rynkach akcji. Wptyw informacji na ceny papierów wartościowych, Oficyna Ekonomiczna, Kraków 2006. 


\section{METODOLOGIA WARUNKOWEJ ANALIZY ZDARZEŃ}

Badanie reakcji cen walorów na określony typ informacji przeprowadzać można różnymi metodami. Jedną z nich jest analiza zdarzeń. Pierwsze badania z zastosowaniem analizy zdarzeń dotyczyły głównie rynku amerykańskiego i dopiero w latach dziewięćdziesiątych XX w. zaczęto ja wykorzystywać na dojrzałych rynkach europejskich. Najnowsze prace pochodzą zaś z mniejszych oraz mniej płynnych rynków wschodzących. W Polsce badania z wykorzystaniem analizy zdarzeń przeprowadzano dopiero po 2000 r. i dotyczyły one głównie komunikatów wydawanych przez przedstawicieli spółki. Natomiast mało jest badań dotyczących ogólnej reakcji polskiego rynku akcji na ogłoszenia makroekonomiczne, a były one przeprowadzane m.in. przez H. Gurgula ${ }^{9}$ oraz B. Będowską-Sójkę ${ }^{10}$. Należy zauważyć, że tylko część badań dotyczących tego typu informacji została zrealizowana zgodnie $\mathrm{z}$ metodyka, przedstawionej w pracy, warunkowej analizy zdarzeń (wykorzystywano również klasyczną analizę zdarzeń) ${ }^{11}$.

Modelami wykorzystywanymi w warunkowej analizie zdarzeń są modele należące do grupy ARMA-GARCH (Autoregressive and Moving Average - Generalized Autoregressive Conditional Heteroskedasticity). Zastosowanie tych modeli pozwala na określenie nie tylko oczekiwanego poziom stopy zwrotu, lecz także oczekiwanego poziom wariancji stóp zwrotu. Na potrzeby prezentacji modelu ARMA-GARCH przyjęto następujące oznaczenia:

$R_{t}$ - stopa zwrotu waloru w chwili $t$,

$\mu_{t}$ - warunkowa wartość oczekiwana stopy zwrotu waloru pod warunkiem zbioru informacji $\mathscr{F}_{t-1}$ - dotyczących badanego waloru dostępnych do chwili $t-1$ włącznie,

$y_{t}-$ składnik losowy waloru $\mathrm{w}$ chwili $t$, szok, innowacja instrumentu finansowego,

$x_{k, t}-k$-ta dodatkowa zmienna objaśniająca w równaniu średniej warunkowej w chwili $t$,

$\sigma_{t}^{2}$ - wariancja warunkowa składnika losowego pochodzącego z równania średniej w chwili $t$,

$s_{k, t}-k$-ta dodatkowa zmienna objaśniająca $\mathrm{w}$ równaniu wariancji warunkowej w chwili $t$.

Ogólna postać modelu $\operatorname{ARMA}(m, n)-\operatorname{GARCH}(p, q)$ ze zmienną dodatkowa w równaniu średniej oraz wariancji warunkowej ma następującą postać:

$$
R_{t}=\mu_{t}+y_{t}
$$

\footnotetext{
${ }^{9}$ H. Gurgula, op. cit.

${ }^{10}$ B. Będowska-Sójka, Intraday CAC40, DAX and WIG20 Returns When the American Macro News Is Announced, „Bank i Kredyt” 2010, nr 2, s. 7-20.

${ }^{11}$ B. Będowska-Sójka, Event Study Analysis with Market Model and GARCH Modeling: Announcement of Share Repurchase on the Warsaw Stock Exchange, w: E. Panek (red.), Mathematics in Economics, Wydawnictwo UEP, Poznań 2009, s. 17-33.
} 


$$
\begin{aligned}
& \mu_{t}=a_{0}+\sum_{k=1}^{w} \gamma_{k} x_{k, t}+\sum_{r=1}^{m} a_{r} R_{t-r}+\sum_{s=1}^{n} b_{s} y_{t-s}, \\
& \sigma_{t}^{2}=\omega_{0}+\sum_{i=1}^{p} \beta_{i} \sigma_{t-i}^{2}+\sum_{j=1}^{q} \alpha_{j} y_{t-j}^{2}+\sum_{k=1}^{u} \omega_{k} s_{k, t},
\end{aligned}
$$

gdzie $y=\sigma_{t} \varepsilon_{t}$, takie, że $\varepsilon_{t} \sim i i d(0,1)$ oraz dla dowolnego $i, j: \alpha_{j} \geqslant 0, \beta_{i} \geqslant 0$, $\omega_{0}+\Sigma_{k=1}^{u} \omega_{k} s_{k, t}>0$ dla dowolnego $t=1, \ldots, T$ ( $T$ jest liczbą obserwacji badanego szeregu). Ponadto warto zaznaczyć, że parametry $\alpha_{j}$ określają wpływ szoków z poprzednich $q$ okresów na warunkową wariancję, parametry $\beta_{i}$ odzwierciedlaja zaś wpływ warunkowej zmienności zaobserwowanej w $p$ poprzednich okresach $^{12}$.

Ponieważ $\varepsilon_{t}$ jest ciągiem niezależnych zmiennych losowych o tym samym rozkładzie z zerową średnią i jednostkowa wariancja, możliwe jest modelowania szeregów z wykorzystaniem innego rozkładu zmiennej losowej $\varepsilon_{t}$ niż rozkład normalny. W praktyce najczęściej wykorzystywany jest symetryczny lub skośny rozkład $t$-Studenta.

W literaturze przedmiotu wstępuje wiele typów powyższego równania. Równanie wariacji warunkowej może dodatkowo uwzględniać efekt asymetrii stóp zwrotu (np. EGARCH) czy długiej pamięci (np. FIGARCH) ${ }^{13}$.

Warunkową analizę zdarzeń najczęściej stosuje się, gdy badane zdarzenie dla wszystkich firm występuje w tym samym czasie. Wtedy szacowany jest model ze zmienną zero-jedynkową przyjmującą wartość $1 \mathrm{w}$ oknie zdarzenia oraz 0 poza nim. Wówczas indeks $w$ w równaniu średniej warunkowej stopy zwrotu oznacza liczbę rodzajów zdarzeń (liczbę klas) w próbie. Testowanie efektu ogłoszenia informacji polega na badaniu statystycznej istotności parametrów stojących przy zmiennych zero-jedynkowych opisanych równaniami:

$$
\begin{gathered}
x_{k, t}=\left\{\begin{array}{l}
1, t \text { należy do okna zdarzenia } \\
0, \text { w pozostałych przypadkach }
\end{array},\right. \\
s_{k, t}=\left\{\begin{array}{l}
1, t \text { należy do okna zdarzenia } \\
0, \text { w pozostałych przypadkach }
\end{array}\right.
\end{gathered}
$$

\section{CHARAKTERYSTYKA ZDARZENIA ,INFORMACJA RADY POLITYKI PIENIĘŻNEJ O ZMIANIE STOPY REFERENCYJNEJ"}

Od 1998 r. Narodowy Bank Polski realizuje strategię bezpośredniego celu inflacyjnego (BCI). Początkowo Rada Polityki Pieniężnej określiła, że średniookresowym celem polityki pieniężnej jest obniżenie w latach 1998-2003 stopy

\footnotetext{
${ }^{12}$ M. Doman, R. Doman, Modelowanie zmienności i ryzyka, Metody ekonometrii finansowej, Wolters Kluwer, Kraków 2009, s. 78 i 85.

13 Ibidem, s. 105-138.
} 
wzrostu cen towarów i usług konsumpcyjnych poniżej $4 \%^{14}$. Następnie po osiagnięciu postawionego sobie celu, od poczatku $2004 \mathrm{r}$. zadaniem NBP jest realizacja ciągłego celu inflacyjnego na poziomie $2,5 \%$ z możliwością wahań $\mathrm{w}$ przedziale $+/-1$ punkt procentowy ${ }^{15}$. Osiągnięcie przez NBP celu inflacyjnego jest możliwe przez kształtowanie krótkoterminowych stóp procentowych na rynku pieniężnym za pomocą podstawowych stóp procentowych instrumentów polityki pieniężnej.

Decyzja o zmianie podstawowych stóp procentowych podejmowana jest na posiedzeniach Rady Polityki Pieniężnej. Harmonogram spotkań ogłaszany jest $\mathrm{z}$ wyprzedzeniem, najczęściej na cały rok kalendarzowy. Znajomość terminu posiedzenia RPP jest ważna z punktu widzenia kształtowania się oczekiwań uczestników rynku co do zmian poziomu podstawowych stóp procentowych. Po każdym posiedzeniu na konferencji prasowej przekazywany jest komunikat o podjętych decyzjach wraz $\mathrm{z}$ ich uzasadnieniem, a następnie publikowany jest on na stronie internetowej NBP oraz w formie uchwały RPP w „Dzienniku Urzędowym Narodowego Banku Polskiego".

Obecna polityka informacyjna NBP jest konsekwencja wprowadzenia $\mathrm{w}$ Polsce strategii bezpośredniego celu inflacyjnego. W ramach tej strategii bank centralny, obok dążenia do osiagnięcia postawionego celu, jest również odpowiedzialny za prowadzenie polityki informacyjnej ${ }^{16}$. Polityka informacyjna banku centralnego oparta jest na zrozumiałym i prostym formułowaniu celów długoterminowych polityki pieniężnej, objaśnianiu sposobów ich realizacji oraz identyfikowaniu i wydawaniu opinii dotyczących zmian zachodzących w kondycji gospodarki. Stąd też NBP, pragnąc ułatwić podmiotom funkcjonującym $\mathrm{w}$ gospodarce zrozumienie realizowanej polityki pieniężnej, prezentuje w czytelny sposób różnego rodzaju raporty (zawierające także prognozy), jak również uzasadnia podjęte decyzje oraz prowadzone działania. Właściwe prowadzona polityka informacyjna zapewnia przejrzystość polityki pieniężnej banku centralnego, która ułatwia kształtowanie oczekiwań, podejmowanie decyzji oraz przyczynia się do poprawy ich trafności ${ }^{17}$. Trafne oczekiwania natomiast zwiększaja wiarygodność polityki banku centralnego, która istotnie i pozytywnie wpływa na poprawę skuteczności polityki realizowanej przez $\mathrm{NBP}^{18}$.

\section{ZAKRES CZASOWY I PODMIOTOWY BADAŃ EMPIRYCZNYCH}

Za początek okresu badawczego przyjęto moment wprowadzenia drugiego etapu realizacji strategii bezpośredniego celu inflacyjnego. Wybór ten uzasadniony jest faktem istnienia zależności pomiędzy oczekiwaniami inwestorów dotyczącymi decyzji RPP o poziomie podstawowych stóp procentowych w gospo-

14 Średniookresowa strategia polityki pieniężnej na lata 1999-2003, Narodowy Bank Polski, s. 9.

${ }_{15}$ Strategia polityki pieniężnej po 2003 roku, Narodowy Bank Polski, Warszawa 2003.

16 Ibidem, s. 11-12.

${ }_{17}$ M. Kowalak, Instytucjonalne podstawy polityki pieniężnej, w: W. Przybylska-Kapuścińska (red.), Wspótczesna polityka pieniężna, Difin, Warszawa 2008, s. 235.

${ }^{18}$ Ibidem, s. 228. 


\section{Wykres 1}

Wysokość oraz zmiany stopy referencyjnej NBP w latach 2004-2011

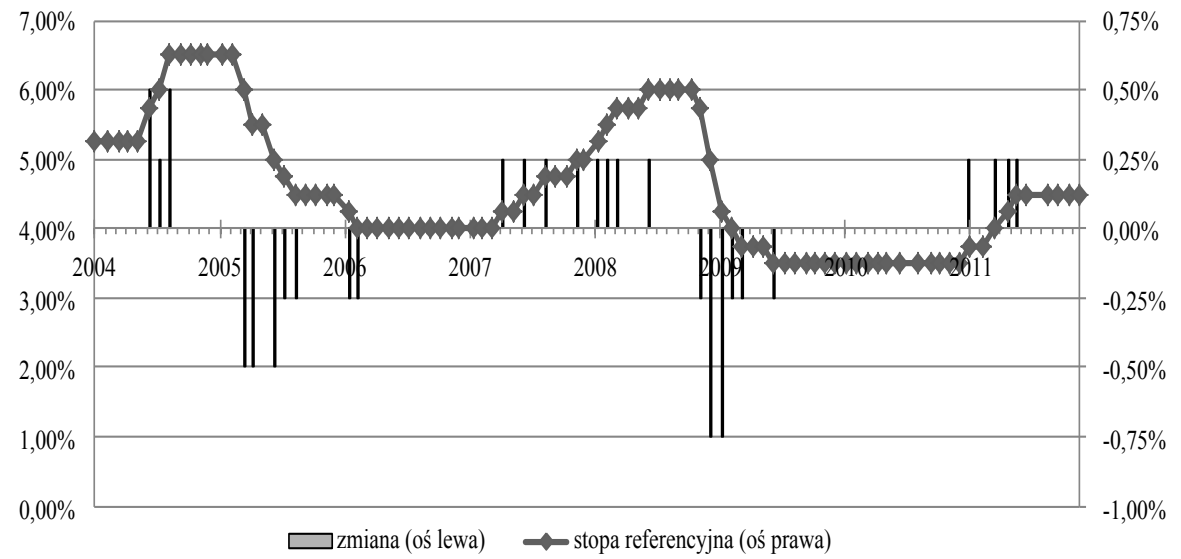

Źródło: opracowanie własne na podstawie komunikatów RPP w latach 2004-2011, publikowanych po posiedzeniach decyzyjnych RPP na: www.nbp.pl.

darce a poprawnym rozumieniem przez nich m.in. strategii oraz celów polityki pieniężnej. Datę końcową badania ustalono na koniec 2011 r., gdyż był ostatni rok, dla którego w chwili rozpoczęcia analiz znane były wszystkie zmiany stóp procentowych NBP.

Aby osiągnąć wyznaczone cele polityki pieniężnej w latach 2004-2011 Rada Polityki Pieniężnej dokonała 28 zmian poziomu stopy referencyjnej, z czego w 15 przypadkach dokonano podwyżki minimalnej rentowności bonów pieniężnych oraz 13-krotnie poziom tej stopy został obniżony. Na pozostałych 65 posiedzeniach RPP podjęła decyzję o pozostawieniu stopy procentowej na niezmienionym poziomie.

Badanie przeprowadzono na podstawie informacji dziewięciu szeregów stóp zwrotu spółek 1 czerwca 2010 r. należących do WIG20 (ich okres notowania obejmował przyjęty okres badawczy 2004-2011). Do badania zakwalifikowano: ASSACEPOL, BRE, BZWBK, GETIN, KGHM, PEKAO, PKNORLEN, POLIMEXMS oraz TPSA. Przesłanką doboru spółek należących właśnie do tego indeksu jest duże zainteresowanie inwestorów ich akcjami, a co za tym idzie płynnościa ich obrotu. Ponadto badania przeprowadzone na potrzeby niniejszego artykułu stanowią kontynuację wcześniejszych badań autorki nad przedstawionym zagadnieniem, dlatego w celu możliwości dokonania stosownych porównań uznano przynależność spółki na dzień 1 czerwca 2010 r. do indeksu WIG20 za jedno z kryteriów doboru spółki do próby, tym samym otrzymując taką samą próbę badawczą jak w badaniach wcześniejszych ${ }^{19}$.

${ }^{19}$ E. Filipowicz, Zmiany stopy referencyjnej NBP a ceny akcji spótek z indeksu WIG20 na GPW $w$ Warszawie, w: D. Wiśniewska (red.), Anomalie gietdowe. Doświadczenia światowe a sytuacja na GPW $w$ Warszawie, Polskie Wydawnictwo Ekonomiczne, Warszawa (przyjęty do druku). 


\section{ANALIZA KSZTAŁTOWANIA SIE STÓP ZWROTU}

Dla szeregu logarytmicznych procentowych stóp zwrotu każdej z dziewięciu spółek poddanych badaniu wyznaczono podstawowe charakterystyki (tabela 1), a następnie przeprowadzono testy weryfikujące liniowe i nieliniowe zależności $\mathrm{w}$ stopach zwrotu oraz testy identyfikujące występowanie zależności długookresowych.

Jak można zauważyć w tabeli 1 , wartość przeciętna stopy zwrotu badanych spółek jest dodatnia, jednak bliska zera. Największe negatywne zmiany stopy zwrotu badanych szeregów, z wyjątkiem PKNORLEN oraz POLIMEXMS, są co do wartości bezwzględnej większe niż ich dodatnie odpowiedniki. Odchylenia standardowe zwrotów spółek są na zbliżonym poziomie. Największą zmiennością stóp zwrotu wokół poziomu średniej arytmetycznej charakteryzuje się KGHM, najmniejszą zaś - TPSA. Ponadto wszystkie badane szeregi stóp zwrotu charakteryzują się istotną wartością nadwyżkowej kurtozy na poziomie istotności 5\%, co wskazywać może na rozkład stóp zwrotu inny niż normalny. Co więcej, tylko w przypadku dwóch spółek: BZWBK oraz PEKAO nie stwierdzono istotnego współczynnika skośności, który świadczy o asymetrii rozkładów ich zwrotów. Hipoteza zerowa testu Jarque-Bera o normalności rozkładu zgodnie z przypuszczeniami autorki została odrzucona we wszystkich przypadkach. Tylko w przypadku szeregu stóp zwrotu spółki ASSACEPOL nie zidentyfikowano zależności linowych $\mathrm{w}$ stopach zwrotu. Natomiast istotne autokorelacje dla wszystkich spółek wykryto w szeregach kwadratów stóp zwrotu. Fakt występowania zależności nieliniowych w zwrotach tych spółek potwierdził przeprowadzony test ARCH. Na podstawie testu Lo tylko w przypadku spółki

Tabela 1

Wartości podstawowe statystyk dla szeregów stóp zwrotu badanych spółek w latach 2004-2011

\begin{tabular}{|l|c|c|c|c|c|c|}
\hline \multicolumn{1}{|c|}{$\begin{array}{c}\text { Nazwa } \\
\text { spółki }\end{array}$} & Min & Średnia & Max & $\begin{array}{c}\text { Odchylenie } \\
\text { standardowe }\end{array}$ & Skośność & $\begin{array}{c}\text { Nadwyżkowa } \\
\text { kurtoza }\end{array}$ \\
\hline ASSECOPOL & $-19,506$ & 0,031 & 13,384 & 2,182 & $\mathbf{- 0 , 2 6 7}$ & $\mathbf{5 , 3 8 7}$ \\
\hline BRE & $-14,150$ & 0,049 & 12,900 & 2,571 & $\mathbf{- 0 , 1 1 3}$ & $\mathbf{3 , 9 0 6}$ \\
\hline BZWBK & $-12,143$ & 0,054 & 11,030 & 2,368 & $-0,008$ & $\mathbf{2 , 4 3 0}$ \\
\hline GETIN & $-45,392$ & 0,073 & 20,125 & 2,888 & $\mathbf{- 1 , 6 0 8}$ & $\mathbf{3 4 , 6 4 5}$ \\
\hline KGHM & $-23,624$ & 0,072 & 17,693 & 2,999 & $\mathbf{- 0 , 5 1 5}$ & $\mathbf{4 , 8 2 6}$ \\
\hline PEKAO & $-20,585$ & 0,013 & 13,556 & 2,526 & $-0,099$ & $\mathbf{4 , 3 2 1}$ \\
\hline PEKNORLEN & $-12,158$ & 0,015 & 12,866 & 2,327 & $\mathbf{- 0 , 1 3 6}$ & $\mathbf{2 , 0 3 7}$ \\
\hline POLIMEXMS & $-11,725$ & 0,067 & 14,537 & 2,739 & $\mathbf{0 , 1 9 0}$ & $\mathbf{3 , 1 1 7}$ \\
\hline TPSA & $-12,017$ & 0,006 & 9,614 & 1,904 & $-0,247$ & 2,283 \\
\hline
\end{tabular}

Źródło: opracowanie własne. 
POLIMEXMS odrzucono hipotezę zerową o braku występowania zależności długookresowych, a dla pozostałych spółek wartość empiryczna statystyki należała do obszaru niekonkluzywności. Stąd przeprowadzono test GPH, którego wyniki pozwoliły odrzucić hipotezę zerową o braku długiej pamięci aż w czterech przypadkach: BRE, GETIN, POLIMEXMS oraz TPSA.

Jak pokazano w części drugiej, występowanie efektu ogłoszeń można weryfikować $\mathrm{w}$ szeregach stóp zwrotu, jak również w oszacowaniach zmienności błędów. Dlatego oszacowano model ARMA-GARCH z dodatkowymi zmiennymi zarówno w modelu średniej, jak i wariancji warunkowej. Ze względu na prowadzenie tych samych dodatkowych zmiennych do równania średniej i wariancji warunkowej, w celu ich odróżnienia wprowadzono następujące oznaczenia:

- podwyżka M oznacza dodatkową zmienną objaśniającą w równaniu średniej warunkowej przyjmująca wartość $1 \mathrm{w}$ dniu podania informacji o podwyższeniu stopy referencyjnej, a $0-\mathrm{w}$ pozostałych dniach,

- obniżka M oznacza dodatkowa zmienną objaśniającą w równaniu średniej warunkowej przyjmującą wartość $1 \mathrm{w}$ dniu podania informacji o obniżeniu stopy referencyjnej, a $0-\mathrm{w}$ pozostałych dniach,

- podwyżka V oznacza dodatkową zmienną objaśniająca w równaniu wariancji warunkowej przyjmującą wartość $1 \mathrm{w}$ dniu podania informacji o podwyższeniu stopy referencyjnej, a $0-\mathrm{w}$ pozostałych dniach,

- obniżka V oznacza dodatkową zmienną objaśniającą w równaniu wariancji warunkowej przyjmującą wartość $1 \mathrm{w}$ dniu podania informacji o obniżeniu stopy referencyjnej, a $0-\mathrm{w}$ pozostałych dniach.

Wyniki oszacowań parametrów modeli ARMA-GARCH przedstawia tabela 2.

W większości przedstawionych modeli parametry stojące przy zero-jedynkowych zmiennych dodatkowych zarówno w modelu średniej, jak i wariancji warunkowej sa nieistotne statystycznie na poziomie 5\%. Jedynie w przypadku dwóch spółek zaobserwowano istotne oszacowania parametrów zmiennych dodatkowych $\mathrm{w}$ równaniu średniej oraz równaniu wariancji. W przypadku spółki BRE otrzymano istotne oszacowania parametrów zmiennych, związanych z ogłoszeniem informacji o podwyższeniu oprocentowania operacji otwartego rynku, występujących zarówno w równaniu średniej, jak i wariancji. Natomiast w przypadku spółki KGHM istotna reakcja wystąpiła w równaniu średniej w związku z podaniem informacji o obniżeniu stopy referencyjnej, w równaniu wariancji zaś na skutek podania informacji o podwyższeniu stóp procentowych NBP. Dodatkowo w przypadku obu spółek istotne parametry zmiennych zero-jedynkowych występujących w równaniu średniej mają znak ujemny. W przypadku spółki BRE kierunek reakcji stóp zwrotu jest zgodny $\mathrm{z}$ oczekiwanym - jest negatywny, natomiast w przypadku drugiej spółki kierunek reakcji jest pozytywny. Ponadto istotne oszacowanie parametru przy zmiennej ,,podwyżki V” otrzymane dla spółki BRE oraz KGHM przyjmują znak ujemny. Uwzględniając fakt, że w przypadku tych samych spółek oraz dłuższego okna zdarzenia - obejmującego trzy dni przed zajściem zdarzenia, dzień zdarzenia oraz trzy dni po ogłoszeniu informacji -4 z 5 (pozostałe 15 było nieistotne) istotnych parametrów miały znak dodatni bez względu na kierunek 


\begin{tabular}{|c|c|c|c|c|c|c|c|c|c|c|c|}
\hline 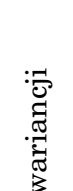 & 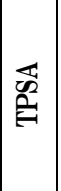 & 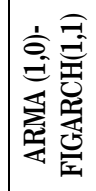 & . & 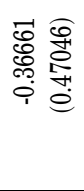 & 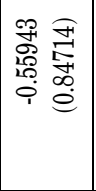 & 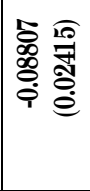 & ' & ' & 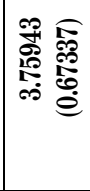 & 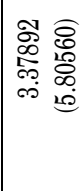 & 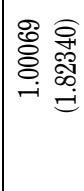 \\
\hline 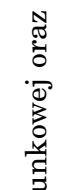 & 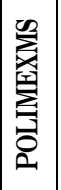 & 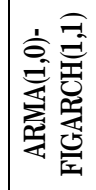 & . & 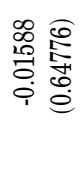 & 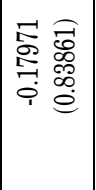 & 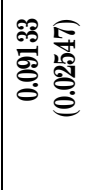 & ' & ' & ' & 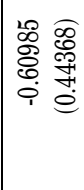 & 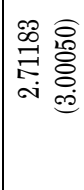 \\
\hline 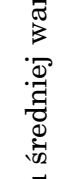 & 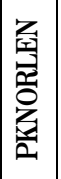 & 宗忌 & ' & 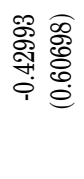 & 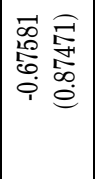 & 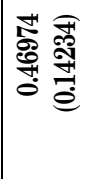 & 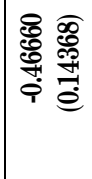 & 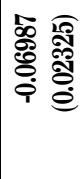 & 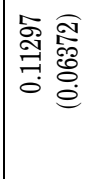 & 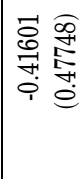 & 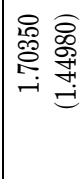 \\
\hline 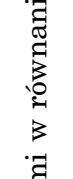 & 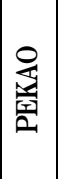 & 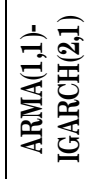 & ' & 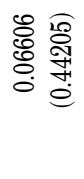 & 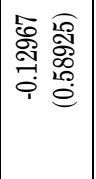 & 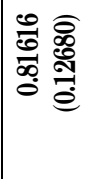 & 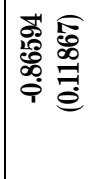 & ' & 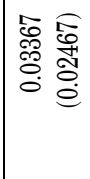 & 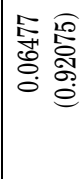 & 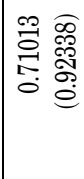 \\
\hline 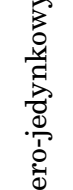 & 焉 & 灾気 & 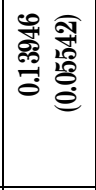 & 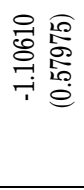 & 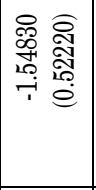 & 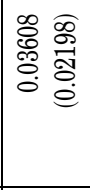 & ' & ' & 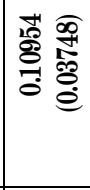 & 害寻 & 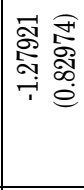 \\
\hline 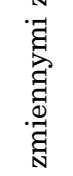 & 忘 & 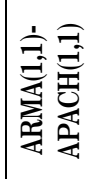 & 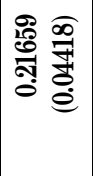 & 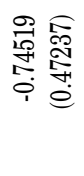 & 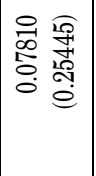 & 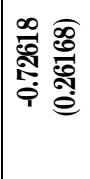 & 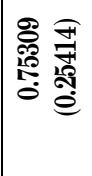 & 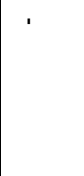 & 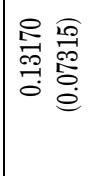 & 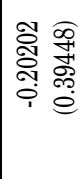 & 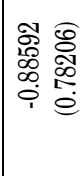 \\
\hline 焉 & 放 & 灾奈 & 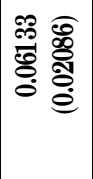 & 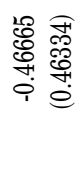 & 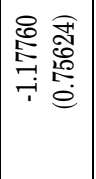 & 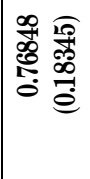 & 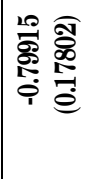 & ' & ' & 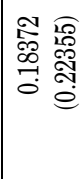 & 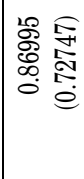 \\
\hline 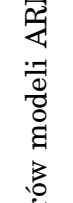 & 黛 & 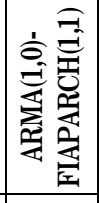 & 席 & 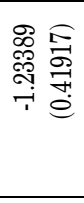 & 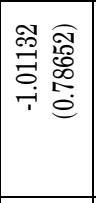 & 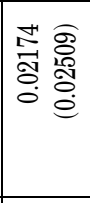 & & ' & 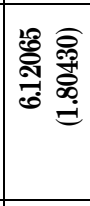 & 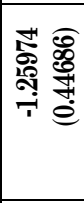 & 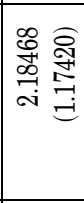 \\
\hline 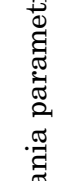 & 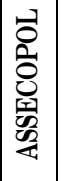 & 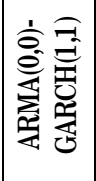 & ' & 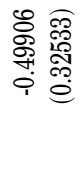 & 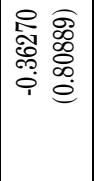 & . & & ' & 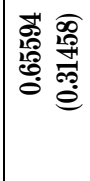 & 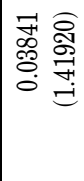 & 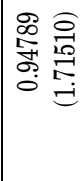 \\
\hline $\begin{array}{l}0 \\
\mathbb{N} \\
\text { N } \\
0 \\
0\end{array}$ & \begin{tabular}{|c|}
$\frac{\pi}{4}$ \\
章 \\
की \\
की
\end{tabular} & $\begin{array}{l}\overline{0} \\
\frac{0}{2}\end{array}$ & $\approx$ & 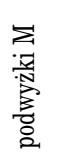 & 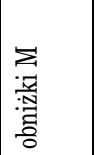 & $\sigma^{\top}$ & 0 & $\Omega^{2}$ & $3^{0}$ & 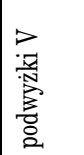 & 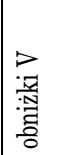 \\
\hline
\end{tabular}




\begin{tabular}{|c|c|c|c|c|c|c|c|c|c|c|}
\hline 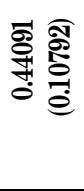 & ' & 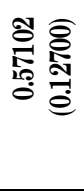 & ' & 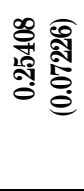 & & ' & 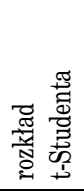 & 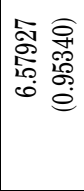 & . & \\
\hline 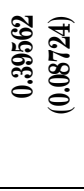 & ' & 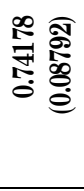 & ' & 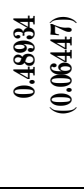 & ' & ' & 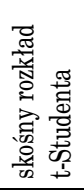 & ' & 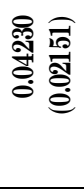 & 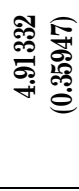 \\
\hline 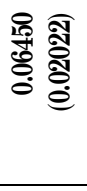 & ' & 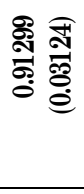 & ' & ' & . & ' & 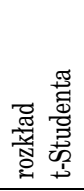 & 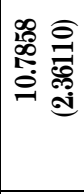 & . & . \\
\hline 韋 & ' & $\frac{\text { 突 }}{\text { 学 }}$ & 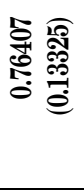 & ' & ' & ' & 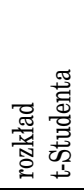 & 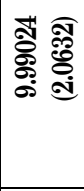 & ' & ' \\
\hline 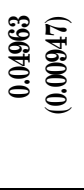 & ' & 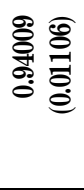 & ' & ' & . & . & 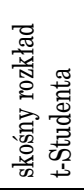 & ' & 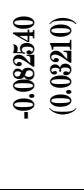 & 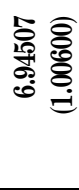 \\
\hline 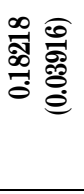 & ' & 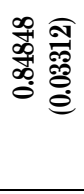 & ' & ' & 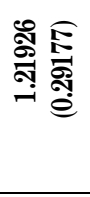 & 0 & 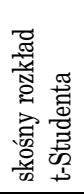 & . & 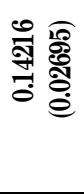 & 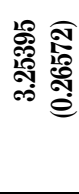 \\
\hline 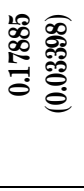 & 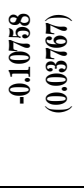 &  & ' & ' & ' & ' & 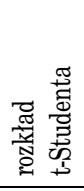 & 总 & ' & \\
\hline 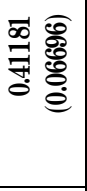 & ' & 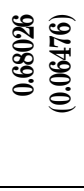 & ' & 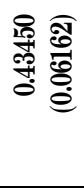 & 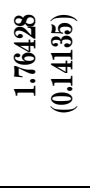 & 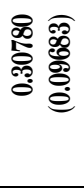 & 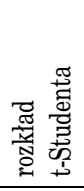 & 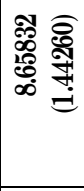 & ' & \\
\hline 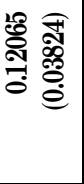 & ' & 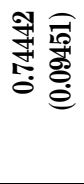 & ' & ' & & ' & 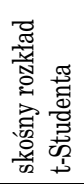 & ' & 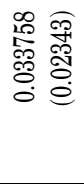 & 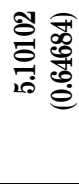 \\
\hline $\overrightarrow{8}$ & $\widetilde{\delta}$ & 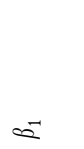 & $a^{2}$ & 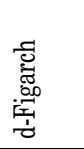 & $\infty$ & $\Rightarrow$ & 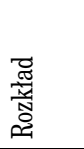 & 兵 & 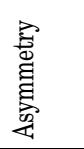 & $\begin{array}{l}\overline{\widetilde{\varpi}} \\
\text { ") }\end{array}$ \\
\hline
\end{tabular}




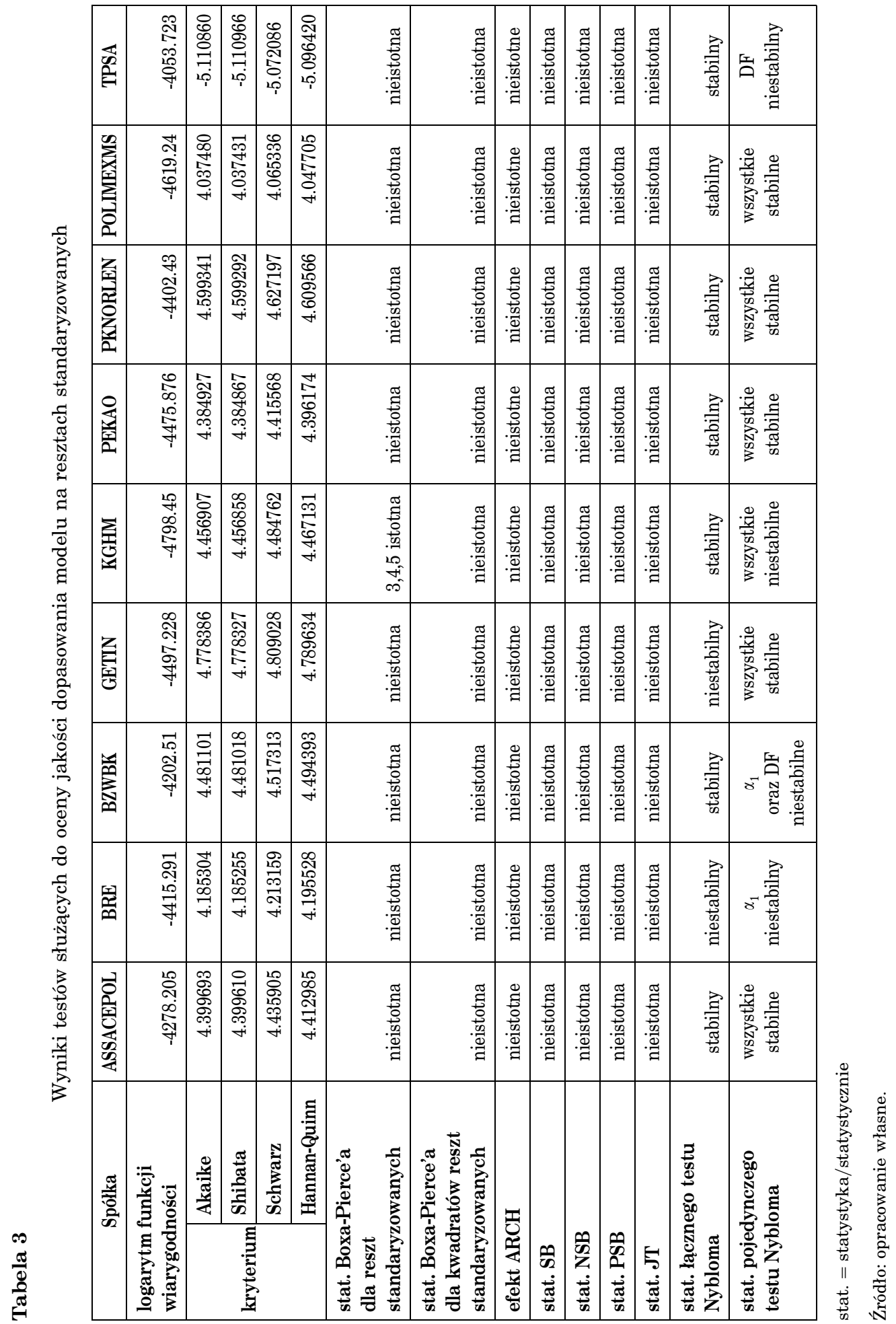


decyzji RPP ${ }^{20}$, otrzymany w niniejszym badaniu ujemny znak dla parametru „,podwyżki V” oznaczać może kształtowanie oczekiwań inwestorów i zawieranie zgodnych z nimi transakcji jeszcze przed dniem podania informacji.

Zawarte w tabeli 2 oszacowania parametrów modelu ARMA-GARCH charakteryzują się najlepszą jakością dopasowania modelu, jaką udało się uzyskać autorce. W przypadku ośmiu spółek (z wyjątkiem KGHM) nie stwierdzono zależności linowych w stopach zwrotu, czyli hipoteza zerowa testu Boxa-Pierce'a dla reszt standaryzowanych nie zostało odrzucona. Nie było podstaw do odrzucenia hipotezy zerowej tego testu również w przypadku szeregu kwadratów reszt standaryzowanych. Ponadto hipoteza zerowa testu ARCH nie została odrzucona, co przemawia za brakiem zależności nieliniowych w standaryzowanych resztach z modelu. Dodatkowo nie wykryto w szeregach reszt standaryzowanych zależności asymetrycznych. Niestety w przypadku spółek BRE i GETIN wystąpił problem ze stabilnością wektora parametrów, a spółki KGHM - problem ze stabilnością poszczególnych parametrów modelu.

Podsumowując wyniki, można stwierdzić, że choć dołożono wszelkich starań, niektóre otrzymane modele nie spełniały wszystkich standardów będących wyznacznikiem dobrej jakości dopasowania modelu ARMA-GARCH. W praktyce taka sytuacja nie jest jednak wyjątkowa (szczególnie w wypadku kilku dodatkowych zmiennych w modelu). Za ważniejszy wniosek poznawczy można jednak uznać to, że tylko w nielicznych przypadkach ogłoszenie zmiany stopy referencyjnej NBP miało wpływ na kształtowanie się zmian cen akcji. Należy jednak zauważyć, że zaobserwowana reakcja wystapiła jednak w modelach, których stabilność parametrów została zakwestionowana, a co za tym idzie wiarygodność tych parametrów jest wątpliwa.

\section{ZAKOŃCZENIE}

Wykazany w badaniu brak istotności parametrów przy zmiennych wyrażających ogłoszenie Rady Polityki Pieniężnej o zmianie stopy referencyjnej, zarówno w równaniu warunkowej średniej oraz wariancji oznacza, że decyzje Rady sa dobrze antycypowane przez rynek. Dodatkowo rezultaty badań sa zgodne z wynikami uzyskanymi na rynkach zagranicznych. Szczególnie interesujący jest spadek zmienności $\mathrm{w}$ dniu podania informacji przez RPP, zaobserwowany w przypadku dwóch spółek. Można go interpretować, w odniesieniu do wcześniejszych badań, jako kształtowanie się oczekiwań inwestorów przed dniem zajścia zdarzenia. Jednakże reakcja ta może wynikać z uzasadnienia na konferencji prasowej podjętej decyzji przez przedstawicieli NBP i RPP. Takie uzasadnienie podjętych decyzji przyczynia się do właściwego rozumienia prowadzonej polityki pieniężnej, a wskutek tego - do usunięcia niepewności inwestorów dotyczącej przyszłych decyzji Rady oraz przyczynia się do uspokojenia inwestorów (rynku). Brak reakcji rynku wykazany w badaniu

20 Ibidem. 
pozwala zatem pozytywnie ocenić politykę informacyjną Narodowego Banku Polskiego, nie wklucza on jednak możliwości wystąpienia reakcji rynku w zwrotach śróddziennych. Fakt ten stanowi asumpt do dalszych badań.

mgr Ewa Filipowicz

Uniwersytet Ekonomiczny w Poznaniu

\title{
ASSESSMENT OF THE REACTION STOCK RETURNS TO THE CHANGES IN THE OPEN MARKET OPERATION RATE - CONDITIONAL EVENT STUDY ANALYSIS
}

\author{
Summary
}

The paper is devoted to the response of Polish stock returns to the announcement of changes in the open market operation rate. The reaction was examined using a conditional event study analysis. The knowledge of the reaction of returns is very important for investors who make investment based on that knowledge which then often contributes to earning above-average profits. Additionally, owing to the type of information, it may also be considered as an element of the transparency of monetary policy.

The paper is divided into five parts. The first one contains a summary of similar studies conducted in foreign markets. The second presents the methodology of a conditional event study analysis. The third part is devoted to the characteristics of the studied event. The fourth part explains the choice of time and personal scope of the study, while the last provides the results. 
Copyright of Journal of Law, Economics and Sociology is the property of Faculty of Law and Administration of Adam Mickiewicz University in Poznan and its content may not be copied or emailed to multiple sites or posted to a listserv without the copyright holder's express written permission. However, users may print, download, or email articles for individual use.

Właścicielem praw autorskich do „Ruchu Prawniczego, Ekonomicznego i Socjologicznego” jest Wydział Prawa i Administracji Uniwersytetu im. Adama Mickiewicza w Poznaniu. Zawartość czasopisma nie może być kopiowana, przesyłana do innych stron internetowych bądź zamieszczana na blogach bez pisemnej zgody wydawcy. Niemniej artykuły można drukować, kopiować lub przesyłać w formie elektronicznej na własny użytek. 